\title{
The New German Nature Lyric
}

\author{
Nicola Thomas \\ Department of Comparative Literature and Culture, Queen Mary University of London, London E1 4NS, UK; \\ nicola.thomas@qmul.ac.uk
}

Received: 1 April 2020; Accepted: 12 May 2020; Published: 4 June 2020

\begin{abstract}
Naturlyrik has long been a contested category in German poetry, but however politically suspect some may find 'Gespräch(e) über Bäume' (Brecht), they are vitally important in the era of anthropogenic environmental collapse. The current generation of German-language poets have sought new ways of writing about the natural world and environments; these differ from, and draw on, pre-twentieth-century Naturlyrik as well as the complex, often critical, representations of nature in poetry after the Second World War. Representations of gardens and other human-'managed' natural spaces, references to and rewritings of German literary tradition, and the exploration of non-human voices and subjects all serve as means of restoring subjective fullness and complexity to Naturlyrik. The questions of voice and form which are central to the idea of the lyric genre as a whole are implicated in the development of a contemporary nature poetry beyond both Brecht and Benn, and Anthropocene Naturlyrik is pushing German lyric poetry itself into a new phase.
\end{abstract}

Keywords: ecocriticism; nature poetry; Naturlyrik; Yoko Tawada; Jan Wagner; Ulrike Draesner; Silke Scheuermann; lyric subject

\section{Introduction}

The last ten years have seen a new blossoming of what might be called Naturlyrik (nature poetry) or Ökolyrik (eco-poetry) in German-language literature. This has caught some critics by surprise, given that nature poetry is a contested category in German language literature. ${ }^{1}$ In spite, or perhaps because, of the genre's long and illustrious history in German-language literatures between the seventeenth and twentieth centuries, from Goethe and Eichendorff to Rilke and George, Lehmann and Langgässer, poets of the immediate post-war era famously struggled to reconcile the use of images and ideas from the natural world with the perceived ethical responsibilities of poetry. This essay considers developments in German-language nature poetry from the second decade of the twenty-first century in the light of these historical and intellectual problems. ${ }^{2}$ The ethical crises of the mid-twentieth century-bookended by Brecht's apparent rejection of 'Gespräch(e) über Bäume' in 1939 (conversations about trees) and

1 Wendy Anne Kopisch has demonstrated the elusiveness of Naturlyrik (nature poetry), which is at once both deeply familiar and demonstrably imprecise (Kopisch 2012). The term Ökolyrik emerged as an alternative in the late 1980s and early 1990s, intending to highlight the newly political force of nature poetry in the context of a growing awareness of environmental issues (Kohlross 2000, pp. 11-12). This article examines the work of numerous poets whose writing intersects with both the traditions of Naturlyrik and those of politically-engaged Ökolyrik. I use the English phrase 'nature poetry' or 'nature lyric' throughout to translate Naturlyrik and retain the German term Ökolyrik to refer to the German-language tradition of politically-engaged poetry about the natural world, to avoid confusion with the related but distinct Anglophone genre of eco-poetry.

2 Geist (2009) and Goodbody $(2016,2017)$ have provided thorough analyses of the role nature plays in German poetry up to 2010. Some of the patterns they identify continue in post-2010 nature writing-making nature strange, for example, as highlighted by Geist, or the political impulse emphasized by Goodbody. However, German nature poetry since 2010 has continued to develop distinctive modes of expression: Geist's suggestion that the latest generation of German poets write 'after nature' holds less validity for this most recent crop of publications, which tend to position the natural and the human as deeply interconnected. 
Bachmann's disavowal of the 'Mandelblüte' (almond blossom) of metaphor in 1968 (Brecht 1988; Bachmann 1998)-have taken new shapes and forms in the late twentieth and early twenty-first century. ${ }^{3}$ The immediate context of these developments can be traced back to the divided German (and European) landscapes of the Cold War era, through the rise of the Green movement, into a period-the present-in which a deep engagement with the non-human world is not a distraction from the political and material reality of human existence, but absolutely central to the continued survival of human life on Earth. The Ökolyrik of the late 1960s and 1970s in both the German Democratic Republic (GDR) and Federal Republic of Germany (FRG) had already begun to establish modes of writing about nature which engaged with the changing climate and intersected with politically-engaged environmental movements; but, in what has been termed the Anthropocene, it can be argued that any poetry except nature poetry is morally suspect, overlooking as it does the central social and political crisis of the age: the simultaneous collapse of multiple environmental systems brought about by the actions of human beings.

This environmental crisis is, of course, a global one; but German-language nature poetry in particular is in a difficult position when it comes to addressing it. Three distinct challenges face contemporary German nature poets. First, poets writing in German must contend with a long legacy of Western-canonical nature writing which has shaped and informed the global currents of Romantic and neo-Romantic nature poetry in a multitude of languages. Secondly, they must also overcome the lingering post-war feeling that nature poetry is an ethical cul-de-sac, that to write poems about nature is to abdicate one's political responsibilities. Finally, in common with those working in other language-traditions, they must also address the current climate crisis with urgency, and in terms which acknowledge the driving role of wealthy late capitalist nation-states like Germany, Austria, and Switzerland in bringing this crisis about.

In light of this triple bind, one might wonder at the fact that so much contemporary German poetry manages to deal with the natural world in a multitude of interesting ways-with its landscapes, spaces and places; its inhabitants (human and nonhuman); and its politics. The new generation of German nature poets working since 2010 have found innovative ways of confronting this urgent necessity. Writers including those addressed in this article-Yoko Tawada, Jan Wagner, Silke Scheumann, and Ulrike Draesner-have all produced, in the second decade of the twenty-first century, collections or work in German which deal with the complex inheritance of German-language Naturlyrik and Ökolyrik. Surveying their diverse practices, one recognizes the emergence of a new, vital poetics which does justice to the imbrication of the human and the non-human, the literary present and the literary past, and the self with others in ways which challenge the basis of lyric subjectivity.

These interests play out in several key overlaps of motif and theme; for one thing, several of these poets write about the interface of the human and non-human via images of domesticated or tamed nature. Several also explore their themes through a persistent interest in voice, performance, and embodiment; others are interested in confronting aesthetic tradition more directly, either via citation and allusion to other literary texts or via ekphrasis. Taking these developments in turn and tracing patterns and relationships between the work of different writers, I will examine recent currents in German nature poetry, ultimately showing how the questions of voice and form which are central to the idea of the lyric genre as a whole are affected by this development of a contemporary German-language nature poetry: the new German nature poetry grows in new directions and pushes lyric poetry itself into a new phase.

\section{Domesticated Nature}

The relationship between the human and the non-human, whether antagonistic or harmonious, has long been a central concern of both Naturlyrik and Ökolyrik-one might think, for example,

3 All translations are my own. 
of the landscape garden motif in Goethe, Eichendorff, George and Sarah Kirsch, among others, which re-emerges in contemporary German-language nature poetry as one of several ways of examining landscapes rendered subject to the human will. In Yoko Tawada's long narrative poem, Ein Balkonplatz für flüchtige Abende (A Spot on the Balcony for Passing Evenings, hereafter Balkonplatz), the balcony garden of the title, which is mentioned only in passing within the narrative, is best understood as the poem itself: a contingent, overgrown space of escape and possibility which overlooks the whole world. A crucial early meeting between two characters occurs in a botanic garden which is conflated with the space of a theater, suggesting the intermingling of human and non-human culture. ${ }^{4}$ In Silke Scheuermann's Skizze vom Gras, gardens and gardening are a recurrent theme, expressed as the object of longing in 'Flora's Lied' - 'Ich plädiere für Gärten, zieht in Gärten, lebt dort, | Gärten als Gegenform des Paradieses' (I make the case for gardens: move into gardens, live in them, I gardens as the counterpart of paradise) (Scheuermann 2014, p. 44).

The most well-known contemporary German-language garden poet, however, is undoubtedly Jan Wagner. Throughout Wagner's work, the gardener's modest ambition to tame, know, or profit from a patch of the natural world is the starting point for small reflections on the place of the human in the landscape, and, by extension, the world. 'giersch', for example, the opening poem of Wagner's 2016 collection Regentonnenvariationen (Variations on a Water Butt), imagines ground elder, its German name containing the word 'Gier' or greed, rapaciously invading human territory-'(er) kehrt zurück wie eine alte schuld' (Wagner 2016, p. 7). First it colonizes neglected spaces and grows in gaps, but eventually it rises threateningly until it is as high as the gables of the house and fills the entire garden. Other poems also deal with familiar wild plants which occupy the fringes of domestic space: 'melde' traces lines of Chenopodium album, a weed known in English by the common name 'fat hen'; 'maulbeeren' describes mulberry picking on the fringes of a town; in 'morchel', the speaker forages wild morels (Wagner 2016, pp. 26, 33, 35). Elsewhere Wagner writes about such suburban garden banalities as koi carp, fences, and water butts, prompting the critic George Diez to appraise his engagement with nature as kitsch and tedious (Diez 2015). In the sequence of haiku which gives the collection its name, the dark silence of a gardener's water butt is described from a variety of perspectives, through various seasons and weather conditions. Its interior has a mysterious metaphysical significance for the gardener who peers into it:

$$
\begin{aligned}
& \text { unterm pflaumenbaum } \\
& \text { hinterm haus - gelassen, kühl } \\
& \text { wie ein zenmeister } \\
& (\ldots) \\
& \text { als steige durch sie } \\
& \text { die unterwelt hinauf, um } \\
& \text { uns zu belauschen } \\
& \text { (...) } \\
& \text { ein grübeln, grüblen; } \\
& \text { im winter die erleuchtung } \\
& \text { als scheibe von eis } \\
& \text { (under the plum tree } \\
& \text { behind the house - calm, cool } \\
& \text { as a zen master }
\end{aligned}
$$

4 Marion Poschmann, another contemporary poet whose work draws on traditions of Naturlyrik, named her 2016 collection Geliehene Landschaften (Borrowed Landscapes) after the practice within garden design of 'borrowing scenery' from the surrounding landscape, again suggesting the poem itself as a microcosmic viewing point which opens onto a wider world. 


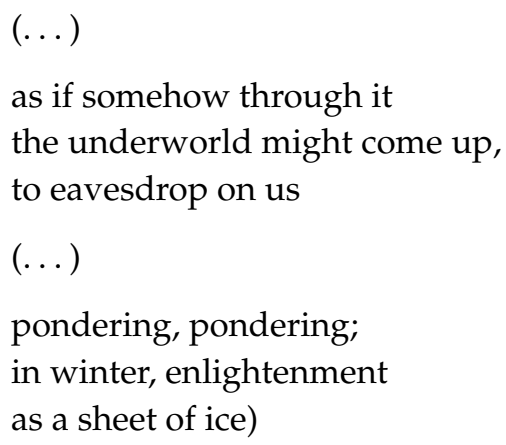

(Wagner 2016, p. 76)

The silvery surface of the water is sometimes a mirror, sometimes a portal to other worlds, before becoming, in the final haiku, a sheet of ice which illuminates human existence. Gardening, the process of taming nature to suit human needs, material and aesthetic, ends up teaching us something about ourselves. There is a clear cultural pedigree, from Goethe to George, to the image of the gardener or garden designer as nature's ultimate sympathetic collaborator; but the pleasure of seeing ourselves reflected in our works of garden-art can arguably also be read as a narcissistic ordering of the cosmos to meet our human needs, as the great landscape gardening projects of early modernity suggest, especially because the ethical value of gardening is somewhat uncertain in an age of sterile lawns and aggressive pesticide use.

Wagner's sequence of 'kalifornische sonette' (californian sonnets), from 2018's Die Live Butterfly-Show, shows a different image of gardens and tamed landscapes, painting them as illusory and artificial idylls which conceal unsustainable forms of living (Wagner 2018, pp. 45-51). These seven sonnets, numbered in descending order, examine a landscape of larger-than-life nature (as it appears to the European visitor) which, when experienced alongside the layers of artifice in the built environment, often tips over into menace; ultimately, as we will see, the sequence confronts the question of how it is possible to live in this beautiful yet stultifying artificial place.

The opening poem, sonnet VII, begins on a Biblical note, the Californian light seeming to bear upon it wildly colorful and ornate flora and fauna, a celebration of nature: a hummingbird, a hibiscus, a monarch butterfly (Wagner 2018, p. 45). The verb, 'gebären', to give birth to, invokes implications of fecundity and maternal bliss. The lyric speaker looks out of the window of a house with sweeping vistas of the sea, and a series of contrasts are rapidly sketched: between the light, colorful, productive activities of the birds and flowers in the opening quatrain and the dark prairie, 'pumaäugig lauernd' (lurking, puma-eyed), in the first tercet. Finally, at the poem's conclusion, at sunset, the artificial lights of a fairground attraction on the pier take over from the natural excess depicted in the opening quatrain, rising up 'als blüte' (like blossoms), an image which draws together the man-made and the botanical. With the exception of the 'gelbrote' (yellow-red) nectar consumed by the butterflies (which the speaker seems unlikely to be able to perceive at first hand), no other color is mentioned with any specificity. The overall effect is of a contrast between the presence and absence of color and light; specific detail is oddly absent.

The contrast between light and dark is also underpinned by a contrast between moist and arid, from the 'bucht and ihre segel' (bay with its sails), reminiscent of Brecht, to the 'dürre hügel' (barren hills) in the distance which conceal other, more menacing, animals. Here, a central problem of the Californian landscape is introduced, namely drought, a long-standing issue for a region in which dense population and intensive agriculture create significant demand for water which cannot sustainably be met using available natural resources. The conflict between human needs and environmental realities is reflected by the gradually melting ice cubes in the speaker's carafe, sign of an eerie and unsustainable excess, an unstable artifice every bit as unnatural as the intense colors of the big wheel on the pier. This discomfiting excess is then transferred back to the light/dark imagery, the rays of the setting sun becoming blinding and disorienting as it sinks over the horizon: 'das licht wie durch ein 
schlüsselloch, | zu groß, als daß man es erkennen könnte' (the light, as if through a keyhole | too big for us to recognize). California is thus cast as a land of extremes and contrasts, between coastal and arid, safe and menacing, hot and cold, light and dark.

The human ability to overcome these extremes and produce a semblance of harmony and control is reflected in the image of the domestic garden. Gardens are explicitly thematized in the next poem in the sequence, VI, with a particular focus on the migrant workers (jardineros) who tend to them, and the fantastical colors of bougainvillea and 'strelitzien', the flower known in English as 'bird-of-paradise' (Wagner 2018, p. 46). Yet once again, this excessive beauty is shown to be supported by an unsustainable resource-intensive infrastructure. Pristine white cubes of washing are compared, ironically, to 'gipfelschnee', the pure white snow of mountain peaks; unlike untouched snow, however, their appearance of absolutely purity and innocence cleverly conceals the human labor and natural resources used to produce them. Again, water is a background issue, from the frozen whiteness of snow to the watering of the garden and washing of the laundry; beauty is underpinned by instability, an unspoken agreement to overlook the long-term consequences of actions.

The next few sonnets in the sequence become gradually more explicit about the perceived menace of this hyperreal, superficially idyllic landscape: the sky is 'blau und glatt' (blue and smooth), weeks of heat cause the swimming pools to melt or dissolve 'wie quallen | auf sand' (like jellyfish | on sand), a vivid image of desiccation and suffering. Appropriately, it is at this key point in sonnet $\mathrm{V}$ at which the poem's key question, the one which is repeated in modified form in the final text of the cycle, is posed: 'könntest du gefallen \| an alldem finden?' (could you find some pleasure || in all this?). The tone is one of skepticism, especially in poem IV-where crows feast on carrion and the link between American agriculture, industrialization, and neoliberal values is neatly gestured towards by the characterization of California as a place where 'milch und gewehre warm sind' (milk and weapons are warm) —and poem III, which refers explicitly to death and absence: 'zum geburtstag in der geisterstadt' (Wagner 2018, pp. 48-49). The motif of water-especially ice-recurs here, in the form of an ice machine, 'die nacht für nacht den kalten rosenkranz | aus würfeln murmelt' (which murmurs night after night $\mid$ its cold rosary of cubes), calling to mind the rapidly melting ice cubes in the opening poem, a reflection of environmental instability. The final lines of this poem bring together the ecocidal agricultural and mining heritage of California, its unstable geology, and the threat of gun violence:

\section{(...) erdreich, durchsiebt von trassen \\ und stollen, und im halbschlaf explosionen \\ tief unten. oder ein paar schüsse draußen.}

(soil riddled with tracks

and tunnels, and, half-asleep, explosions

deep below ground. or a few gunshots outside.)

(Wagner 2018, p. 49)

Here, the industrialized landscape becomes a place of obvious danger, in which the menace hinted at in earlier sonnets comes to the fore.

It is fitting, too, that the final poem explores images of water as a means of breakthrough or possible reconciliation. 'die vögel immerhin' (the birds, at least) it starts, wistfully, suggesting that the birds of California might offer solace in this otherwise strange, dangerous, and alienating place: the hummingbird from poem VII reappears alongside a woodpecker, swallows, and (importantly) water birds: a pelican, gulls, and 'all das zwitschern, pfeifen, trällern' (all the cheeping, whistling, trilling) of a sunset in Malibu (Wagner 2018, p. 51). The penultimate 'tercet' of the sequence is devoted to the deluge of water which follows winter storms; the final 'line' of the tercet, formally speaking, is in fact split across three lines on the page (from 'des surfers' to 'buckelwalen'). This deviation is surprising in a sequence which otherwise adheres quite strictly to the sonnet form; it suggests surplus, overflow, and rupture: 
bevor die winterstürme auf kanälen

und abflußrohren spielen. aufgebockt das brett

des surfers, frisch lackiert, und irgendwo

dort draußen in der ferne ein

convent von buckelwalen

in ihrer eigenen zeit. ob da ein land ist,

in dem sich leben ließe, eine stadt?

es wird zu sehen sein, sobald du landest.

(before the winter storms play in the channels

and sewers. the surfer's board propped up

freshly-painted, and somewhere

out there in the distance a

convent of humpbacks

in their own time. is there a country,

one could live in, a city?

as soon as you land, you'll see.)

(Wagner 2018, p. 51)

'kalifornische sonette' is a sequence concerned with the possibility of living alongside, or within, an eerily artificial tamed natural landscape. California-the quintessentially unsustainable paradise, a symbol of supermodern hyperconsumption and artifice, but also a place inhabited by many beautiful, striking plants, and animals - is obviously the 'da' (there) of the final tercet, an unsettling place for the lyric speaker who clearly feels isolated in this new place. The way the poem engages images of environmental collapse, particularly drought, as a counterpoint to this seductive façade of beauty, color, light, comfort, and luxury, suggests that the speaker's question has a wider relevance: is there, anywhere in the world, a country or city in which one might live without the eerie awareness of the artifices of modern life and the unsustainable exploitation of the natural world on which they are predicated? That the lyric addressee is, we assume, about to conclude a long-haul flight in the poem's final lines suggests that perhaps there is not.

\section{Inherited Nature}

Wagner's use of the sonnet is appropriate, given that the sonnet has long been the signal form of poetic artifice, hiding clever arguments and subtle twists behind its balanced, elegant lines. Wagner has consistently been interested in inherited forms, including haiku (as in 'regentonnenvariationen'), sestina (as in 'anna', 'die tassen' (the cups), 'constable: wolkenstudien' (constable: cloud studies), and villanelles ('doña elba')); he also regularly uses a pentameter line as a kind of formal quotation (Wagner 2016, pp. 76-78, 18, 82; Wagner 2018, pp. 13, 21). In this way, as well as in his renewed approach to the garden themes which have been a feature of German Naturlyrik for centuries, Wagner situates his work in relation to the history of the German-language lyric. He also, quite explicitly at times, reworks and reinterprets that history. Wagner's work thus reflects another of the key tendencies which define the new nature writing in German: a self-conscious engagement with previous artistic representations of the non-human world, in many cases as a means of reflection not just on nature per se but on human cultural representations of 'nature' as they have been constructed in literary history, and what this history reveals about the history of the relationship between the human and non-human in broader ethical terms. In that sense, this intertextual impulse is of a piece with the impulse to explore tamed or domesticated environments, as well as being a means of occupying other skins, part of the shape-shifting impulse discussed in the final part of this analysis.

This applies not only to written representations of the non-human world (including Naturlyrik) but also to painting, visual, and plastic art: ekphrasis is a key means of exploring human/non-human 
relations and the position of humans in the environment for several of the writers considered in this article. Wagner has written poems after Canaletto's depictions of Venice and Constable's cloud-portraits; his texts engage with the formal aesthetic qualities of the works of these other artists-Canaletto's light, Constable's composition-and thus produce an effect of exaggerated form which reveals the constructedness of 'nature'.

Silke Scheuermann's collection Skizze vom Gras (Sketches of Grass), as signaled by the title, is almost entirely structured by intermedial engagements with artistic tradition, both explicit and implicit, including a sequence voicing characters from the commedia dell'arte, one named for the classical motifs of 'Flora und Zephyr', and an eponymous long poem in which the lyric speaker is the daughter of an architect. The sequence 'Helena's Traum' (Helena's Dream), which forms the third part of the collection, is explicitly ekphrastic. This sequence consists of seven poems after works of twentieth and twenty-first century contemporary art, not only paintings (e.g., Picasso's 'Le Repas Frugal', 1904) but also sculpture (e.g., Henry Moore's 'Oval with Points', 1968/1970) and performance works (Vanessa

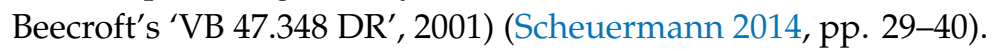

What is striking about the 'Helena's Traum' cycle is how it approaches non-realist works of art which are seemingly not concerned with questions of nature and environment in the traditional sense and situates these in their social, spatial, and environmental context, reading them 'against the grain' to interesting effect. The title poem deals with Marlene Dumas' painting of her daughter, an otherworldly close up of the child's sleeping face; the poem speaks with the voice of the sleeping child, imagining her dreaming of trees and birds. The poem about Moore's 'Oval with Points' situates the sculpture in a public park, witnessing the passage of generations and experiencing a child jumping through the space at the center of its form. The attention paid to the material surrounding of the works, or to the imagined worlds they depict, is a reminder that such instances of shaped matter are key means by which humans relate to our environments, even when 'nature' is not a theme of the work in a superficial sense. Embedding these artworks within a human and non-human framework reminds us that all art is part of nature, and that nature is part of all art.

This is clearly shown by the final poem in the sequence, which speaks with the voice of a relatively early Olafur Eliasson work, 'Spiral Pavilion' (1999/2001). Eliasson is increasingly understood as an artist with a keen interest in the environment, broadly conceived, both theoretical and activist. He is known for his work on weather, form, and the elements. 'Spiral Pavilion' is a half-torus-shaped form constructed for the Venice Biennale in 1995. Eliasson's studio describes it as

an arched circular tunnel constructed from steel tubes. The parallel steel tubes, supported by five arches arranged in a circle, spiral upwards, at an angle from the outer edge of the pavilion and then curve over and down around the inside to the ground, so that each tube completes a full 360 degree circuit. (Studio Olafur Eliasson n.d.)

From a viewer's perspective, the pavilion appears as a shed-sized round wire structure, light and graceful, see-through, yet substantial. Scheuermann's poem speaks with the voice of the sculpture itself, in situ and in context of the elements. In particular, its ability to defy the wind testifies to its hidden power:

Der Wind ist machtlos, er kann nichts verhindern.

Da ich keinen Widerstand biete,

bin ich ungreifbar.

(The wind is powerless, obstructing nothing.

Since I offer no resistance,

I am untouchable.)

(Scheuermann 2014, p. 36) 
The sculpture possesses an instinctive understanding of its surroundings and ability to work with, rather than against, the elements. Humans, in contrast, are seen struggling hopelessly against the wind to make progress. Short but rhythmically balanced lines reflect this sense of elegance under pressure. The poem's second stanza describes the wind in more detail, its destructive effects on landscapes inhabited by humans, and its power as a non-human force which confronts the human:

du wirst zu jemandem, der

seine Augen zur Unendlichkeit wendet.

Sieh ins Innere des Windes, es ist

unbewohnt,

körperlos.

(you will become someone who

turns their eyes to infinity.

Look into the inside of the wind: it is

uninhabited,

incorporeal.)

(ibid., p. 36)

The human being addressed here as ' $\mathrm{du}$ ' lacks capacity to understand the non-human element which is 'uninhabited, incorporeal'. The role of the sculpture, created by a human but dwelling in the elements, is to mediate between human and non-human. This is reflected in the closing stanzas, which position the sculpture in-between heaven and Earth, as a neutral go-between:

Mein Dach zeigt ohne Häme

auf den Boden und schweigt.

Mein Dach zeigt ohne Häme

zum Himmel und öffnet sich den Gebeten.

(My roof points without malice

to the earth and says nothing.

My roof points without malice

to the sky and opens itself to prayers.)

(ibid., pp. 36-37)

This signals the role of art more widely-it is, as above, integrated into 'nature', which encompasses both the human and the non-human. It is a way in which humans make sense of their environments, dwell within those environments and understand them within social, moral, and historical frameworks. Eliasson's ethereal, minimal, resilient pavilion is a paradigmatic example of this, as Scheuermann's poem makes clear.

Both the visual arts and Romantic poetry are important in Tawada's Balkonplatz, a poetic novel in fourteen sections. This text appeared in 2016 at the same time as Akzentfrei (Accentless), a book of literary essays, but while Akzentfrei (as suggested by the title) reprises themes of transcultural identity and playful engagement with the German language familiar from Tawada's earlier work, Balkonplatz marks a departure from her previous lyric and prose works. The text can fruitfully be read in the light of Tawada's 2011 Hamburg lectures on poetics, in which the poet discusses the Tōhoku earthquake-tsunami and subsequent nuclear disaster at Fukushima Daiichi power plant, and in light of which a sharpened focus on environments, ecologies, and crises emerged alongside her other long-standing interests such as language, identity, and cultural exchange (Tawada 2012). Balkonplatz confirms this: its themes are manifold and complex, and it is less obviously a work of Naturlyrik or indeed Ökolyrik than (say) Scheuermann or Wagner's recent collections, but it is a text in which landscapes and animals play a centrally important role, especially in mediating between embodied 
experience and cultural history. Indeed, this is also tied to the representation of water, since the Romantic mythology of Germany's great rivers is brought into play alongside the poem's ostensible opening setting, the harbor landscape of Hamburg:

Elsa summt auf ihrem Balkon.

Ein Fährmann im blau karierten

Hemd seufzt und bleibt stehen unter einer

Loreley, die sich an die

Elbe verirrt hat.

In einer einzigen Nacht

vergehen die Jahrzente.

(Elsa hums on her balcony.

A ferryman in a blue plaid

shirt sighs and stays standing under a

Loreley, who is lost

on the Elbe.

In a single night,

decades pass.)

(Tawada 2016, p. 9)

'Mit Spitzen Ohren' (With Ears Pricked), the ninth of fourteen 'chapters' in Tawada's verse novel, uses modernist visual art (as well as literature) to explore representation and reality in animal and human subjectivity. This section of the poem describes a split between the poem's narrator and one of several love interests, Chris, who moves away to return to his hometown, leaving the protagonist with her female lover. The frame of reference shifts between the texture of dreams and moments of wakefulness, between the world of the poem and the world of various visual artworks with which the poetry is in dialogue. To begin with, the narrator compares Chris unfavorably with an animal companion, exhorting him-in a gender-swapped echo of Fontane's Effi Briest-'sei ein Tier, aber nicht zu wild!' (Tawada 2016, p. 81). The fairytale motif of the frog prince is invoked in their subsequent conversation, with the speaker first threatening to turn Chris into a frog, and then riffing on the famous Matsuo Bashō haiku which reproduces the sound of a frog jumping into an ancient pond. The speaker concludes

Dichten ist ein Austausch: den Wunsch

gegen Buchstaben, das Altern

gegen den Teich und den Frosch

gegen seinen Sprung.

Am Ende bist du nur noch ein Geräusch

im Gehirn. Es klingt nicht jetzt.

Ein totes Wort Ka-wa-zu.

(Writing poems is a trade-off: one's desire swapped

for letters, aging

for the pond and the frog

for its leap.

In the end, you're nothing but a noise

in the brain. That's not the bell.

A dead word, ka-wa-zu.)

(Tawada 2016, p. 82)

The binaries the poem appears to posit are elusive, and ultimately collapse into pure vocables, 'a noise | in the brain' which are severed from (and replace) external 'reality'. The 'you' addressed is also Chris, 
himself a construct of the text. Both await the ringing of the doorbell to announce the arrival of the removal lorry. 'Ka-wa-zu', Basho's word for frog, is a poetic archaism in Japanese, 'drei nasse Silben' (three wet syllables) that no longer designates frogs in the real world, but refers only, in a circular logic, to their poetic representations. As we are told a few lines later, 'Dichter sind Mathematiker der Natur ( ... ) das Reale | gibt es schon lange nicht mehr' (Poets are the mathematicians of nature ( . . ) the real | is long gone, Tawada 2016, p. 82).

Chris petitions not to be turned into a frog, but instead into a tomcat; and here the referential field shifts to the visual arts, prompting a detailed discussion of animals in modernist painting. The cat Chris would like to be is one in a Renoir painting, '(der) an der Brust einer Dame (schlummert)' (slumbering on a lady's bosom); the painting he has in mind is likely 'L'enfant au chat' (1887) a portrait of Julie Manet. But the lyric speaker-protagonist is dissatisfied with his complacency; she notes the absence of animals in Impressionist landscape paintings, and herself prefers post-Impressionist works in which further abstraction weakens the illusion of realism: Gilles Aillaud, Paul Gaugin, Franz Marc. 'Die Tiere im Zoo | kann ich besser verstehen als die in der Natur' (I can understand animals in the zoo | better than those in nature) she explains (Tawada 2016, p. 83), conveying her preference for artifice. Briefly, she imaginatively inhabits the body of the puppies in Gaugin's 'Nature morte avec trois petits chiens' (1888), and they—-the merged speaker/puppy or speaker/puppies, a newly-plural subject—experience the delicate balancing act of placing their paws carefully amongst the clutter of the table.

Chris gets his wish: he is transformed by magic into the tomcat from the Renoir painting, in a sequence with clear intertextual resonances to German fairytales and Kafka's Die Verwandlung: 'das letzte Stück Menschenmöbel | Sofa hieß das Ding früher' (Tawada 2016, p. 84). Several pages later, after vivid descriptions of the animal's physicality and its hygiene routine, the scene again crosses paths with Renoir's 'L'enfant au chat', except with the protagonist (herself an artist) in the role of Julie Manet, and the cat awake while the human sleeps:

Ich bin mit dem halben

Kopf schon eingeschlafen, als der Kater

auf meine Brust steigt.

Für mich ist ein Stilleben auch ein Leben,

für ihn nicht.

(I have already fallen asleep

with half my head, when the tomcat

climbs onto my bosom.

To me, a still life is still a life -

but not to him)

(Tawada 2016, p. 88)

Whether this last sentence alludes to the difference between human and non-human attitudes to artistic representation, or merely the cat's disregard for his owner's naptime, is an open question.

The rest of the section is taken up by further unreal turns of events: the protagonist takes some art postcards from the wardrobe of a dead author who lives nearby and then dreams about giving birth to a cat before waking up in bed with her female partner, Elsa. The post arrives over breakfast, and in addition to a card from Chris (with a stamp featuring a swan; his hometown is called Schwanenberg), there is a postcard depicting an engraving of Adam and Eve by Albrecht Dürer, 'Meister der | Melancholie und des Nashorns' (master of $\mid$ melancholy and rhinoceroses), whose rhinoceros paintings appear elsewhere in the poem (Tawada 2016, p. 92). At Eve's feet, a tomcat lies 'wie eine Fußnote' (like a footnote): 'Eva hat das Tier geboren' (Eve gave birth to the animal), we are told (ibid., p. 92). Furthermore, in a final self-referential twist, we might also make a link to the illustration - much earlier in the text-which shows another Adam and Eve, this one by Suzanne Valladon, arguably the poem's main interlocutor in the visual arts. It is Valladon's portraits which 
serve as a foil to the narrator's multi-faceted lyric subjectivity, and her work gives the characters their physical form in the second part of the poem (ibid., p. 12).

At every stage, Tawada's poem shows that the non-human world is only interpretable via representation, via the multilayered and polyvalent forms of human cultural production and engagement. There is no un-mediated experience of nature as an aesthetic object. This lack of direct access is not to be mourned or regretted-indeed, it is a source of great pleasure and possibility. Through the range of artworks which the poem invokes, from Heine to Kafka, Fontane, Dürer, Gaugin, Cezanne, Monet, Manet, Valladon and many, many others, the imbrication of human and non-human is foregrounded, while the need to work through and with other representations of what we call 'nature' is acknowledged.

\section{Inhabited Nature}

All writers inherit a tradition. Wagner has written and spoken at length about the influence of previous generations of German (and Anglophone) writers on his distinctive poetic voice: from the iambic pentameter rhythms of Heym and Trakl to the commitment to using the lower-case even for nouns, which is reminiscent of both George and 1960s innovators Eugen Gomringer and Ernst Jandl. For Wagner, this type of borrowing and the carefully negotiated relationship to tradition it enables is a form of literary shape-shifting: working through various influences and traditions, the poet adopts and abandons different voices in turn like a series of new skins, each of which, once tried on and shed, leaves his own voice slightly altered (Wagner 2017).

Wagner's critical metaphor for literary influence suggests an attentiveness to physical experience, to the particularities of embodiment, which is also at play in his lyric work, and which might remind us of Tawada's speaker's ability to jump in and out of paintings. He has written poems attending to the physical specificity of plants, animals, vegetables, and man-made objects: radishes, cabbage, huskies, lamprey, martens, elk, whitethorn bushes, mildew, and teabags. Some of these texts belong to the German tradition of the Dinggedicht (thing poem), a genre with an uncertain relationship to Naturlyrik; although Mörike and Rilke's classic Dinggedichte of the nineteenth and early twentieth-century were largely about crafted objects, it is a short step back in literary history to Eichendorff's 'Wünschelrute' and its manifesto for Romantic Natursprache (von Eichendorff 1981).

Clearly, the idea of a lyric poetry which inhabits or gives voice to nature is nothing new. In the age of anthropogenic climate crisis, though, the gesture of inhabiting or embodying animals, plants, and material substances acquires a fresh ethical significance. Careful attention to the body of the non-human other-its perception, proprioception, and putative subjectivity-implies a commitment to decentering the human perspective. This is, as Harriet Tarlo has noted, related to, but not identical with, the post-structuralist's interest in destabilizing the subject per se (Tarlo 2009). Donna Haraway has theorized the 'privilege of partial perspective' as a tool for unleashing the power of situated knowledge, arguing that 'the split and contradictory self is the one who can interrogate positionings and be accountable, the one who can construct and join rational conversations and fantastic imaginings that change history' (Haraway 1988, p. 586). Haraway's feminist critique of scientific objectivity, with its emphasis on situated forms of knowledge, is the basis of her later, more explicitly ecocritical manifesto for 'making kin' with other species and non-human beings (Haraway 2015). As T. J. Welch has suggested in her reading of the American poet Juliana Spahr, lyric poetry has a very definite role to play in enabling human beings to see and inhabit the bodies and voices of non-human entities (Welch 2014).

The current generation of German nature poets has much to contribute to this move towards a new 'eco-ethical poetics' (to borrow Tarlo's phrase) which subverts individual, subjective lyric perspective. Björn Hayer notes that Scheuermann, Wagner, and Poschmann have all written lyric texts which give voice to the subject-position of flowers or plants, linking this to pre-modern discourses of subjectivity in nature (Hayer 2018). Axel Goodbody and Kate Rigby have both discussed the importance within the German tradition of Natursprache, with Goodbody examining its afterlife in more recent German writing as a form of Romantic inheritance in modern German nature poetry (Goodbody 1984). Rigby, 
like Hayer, draws links between Romantic Natursprache and the contemporary scientific discourse of biosemiotics (the study of sign-systems and meaning-making in non-human biological organisms) as a means of exploring the relationship between human and non-human subjectivities (Rigby 2016).

Hayer's reading of 'Flora's Lied' ('Flora's Song') in Skizze vom Gras as a poem which makes visible complex subjectivities and shows the entanglement of human beings and their environments is highly persuasive (Hayer 2018). However, while neo-Romantic biosemiotics provide one useful starting point for reading the collection, Scheuermann's poems are also interested in modes of being and writing which can be explicitly described as post-human. The 'Zweite Schöpfung' (Second Creation) enacted by Scheuermann in the first sequence is, as Hayer neatly observes, undoubtedly linked to the creation of reality in lyric language (Hayer 2018, p. 83). It is also framed as a possibility enabled by biotechnology, setting the scene for the collection of what Martin Ebel describes as 'inverted nature poems' (Ebel 2014) and the paratext to the collection characterizes as 'science fiction poems':

Wie wir es schaffen, hat keine Bedeutung.

Wir hatten seit letztem Sommer schon dicht

am Ziel geforscht.

$[\ldots]$

Ein Tag wird wie der andere sein, wenn wir die Hirne der Großsäuger knacken: ekstatisch, verträumt, voller Verluste. Zweihundert Milliarden

Nervenzellen, aufgelöst, ineinander vertäut wie

Boote im offenen Meer.

(How we achieve it is beside the point.

Since last summer, our project has been close to its objective.

$[\ldots]$

One day will be just like another, when we crack the cerebra of the megafauna: ecstatic, languid, filled with loss. Two hundred billion nerve cells, dissolved, unmoored, intermingled, like boats on the open sea.)

(Scheuermann 2014, p. 11)

Serving as a prologue to the cycle which follows, this poem speaks with the voice of a scientist attempting to revitalize extinct species using biotechnology. The speaker imagines a future in which there is harmony between these newly regenerated creatures and human beings ('Ein Zwergmammut wird | unseren Sohn herumtragen' (A dwarf mammoth will | carry our son around)), and in which individual subjectivity is dissolved into ecstatic oneness within which 'Gehirn, Seele, und Sinne' (brain, body and senses) meld into one. There is both arrogant folly and utopian thinking behind this ideal, and (as the first line, quoted above, indicates) the process is secondary to the assumed outcome. Scheuermann's speaker's desire for unity and entanglement through scientific innovation is decidedly posthuman: the poem explicitly acknowledges the common underlying structures of human and animal brains and bodies, the 'nerve cells' which belong to no one in particular. Human temporality is dissolved and replaced with undifferentiated non-human time- - a process of both gain and loss. This merging of human and animal in the project of overcoming extinction and sparking a 'second Creation' recalls the profound entanglements of post-humanist theory. Here we might think of Haraway's plea that we 'become-with the dead and the extinct', as assemblages of living and dead organisms or 'compost' (Haraway 2015).

At the same time, however, the poem foregrounds human innovation and agency, and it is clear that there is something distinctively human about the speaker's impulse to innovate and create. 
The human perspective is not radically decentered, but rather reinforced as unique: the poem's speaker declares 'Dies ist die Freiheit | unserer Art, neue, andere Arten zu machen. | Gott hat uns mit einem Bausatz beschenkt' (Scheuermann 2014, p. 11). Thus the poem-like the collection as a whole-frames the potential risks and rewards of human scientific innovation against an awareness that human beings are entangled with the non-human world; it also balances the recognition of humans as a species apart (and uniquely destructive), while also characterizing them as part of a wider environmental and ecological tapestry.

Although this poem itself does not adopt the voice of a non-human speaker, it should alter our reading of later texts in Scheuermann's collection, many of which do inhabit non-human subjectivities. If we accept Hayer's argument that the 'Zweite Schöpfung' of the poem is analogous to the conjuring of reality in lyric poetry, we cannot help but see an equivalence between the ambition of the lyric poet who seeks to write from the perspective of a flower or plant and that of the megalomaniac scientist who aims to penetrate and recreate in microcosm the minds of the megafauna. Posthumanism foregrounds the complete interrelation and dependence of human and non-human creations and forms of life; but writing 'on behalf of' a non-human being, far from disrupting anthropocentric norms by subverting the individual lyric perspective, could just as easily end up recentering the human. Put simply: how dare we imagine we know what animals and plants feel and experience? By hinting at this analogy between mad scientist and human poet in 'Zweite Schöpfung', and then going on to speak from inside the consciousness of plants and animals, Scheuermann's collection conducts an exploration of the role of agency-lyric and scientific-in a posthuman assemblage of human and non-human forms of life. It asks to what extent humans are distinct from other beings, to what extent our powers of creation set us apart from them, and-by implication-what it means to speak on their behalf.

Ulrike Draesner's collection Subsong is another exploration of the language and subjectivity of non-human beings. The title of the volume, and its structuring concept, is the ornithological notion of 'subsong': the almost inaudible songs many bird species produce in intimate contexts, especially when nesting, which are markedly different from and more much individuated than their standard territorial vocalizations. ${ }^{5}$ Divided into six sections, the collection begins by considering subsong in the context of language acquisition, and particularly mother-child relationships; it then extends the idea into other forms of intimate relationships, before widening out into cultural engagements which propose the idea of subsong as analogous to poetry itself (Arlaud 2019). Of particular interest to a reading of Draesner's volume as a kind of Naturlyrik or Ökolyrik, however, is the third section, lippkarüi! lippkarüi! (Draesner 2014, pp. 59-114). Here, Draesner explores the vocalizations, subjectivity, and perspective of birds; many (though not all) of the poems in the section address a particular bird in turn. Most are preceded by a kind of epigraph which attempts to capture, using German spelling convention, the subsong of the bird in question; for example, in a poem about a heron:

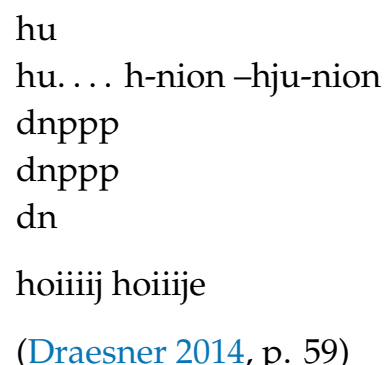

The poems themselves then often play with sounds which emerge from these transcriptions, such that the birdsong itself is enlisted to fulfill the contextualizing role of a conventional epigraph. The majority of the poems themselves retain some form of lyric ' $\mathrm{I}$ ' or 'we', a speaker who may be presumed to be

5 Lyric voice, and its relationship to birdsong, is also important in the work of Ulrike Almut Sandig, whose poetry can at times also be read within the tradition of Naturlyrik or Ökolyrik (Sandig 2011, 2016; Leeder 2018). 
or is explicitly described as human, and many refer to the bird in the third person as 'he' or 'she'. Draesner (like Tawada) playfully and imaginatively occupies the perspective of the bird she treats, and sometimes allows the voice of the poems to merge with the voices of non-human subjects, but the fundamental otherness of animal subjectivity is taken seriously. 'in undurchdringlichen augen zu sehen' (to see in impenetrable eyes) makes this abundantly clear, from the title onwards: the first part of the poem frames the existence of the hornbill against a deep geological and evolutionary timeframe which predates human culture and even the hornbill's own coming into being: 'uraltes | segnen der erde zirpen der insekten und keine | vögel noch fliegen' (ancient | blessing of the earth chirping of the insect and no | birds yet flying). It ends with a statement of human otherness from animals and our connection with, yet fundamental separation from, their subjectivity:

schau, unter den vögeln

bewegt einzig wir

das zart behaarte

gefältelte auge

scha-hau, wie es die grenzen

anderer reiche und ihrer

tümer

bekränzt

(look, below the birds

just us moving

lightly downy

folded eye

lo-ok, how the limits

of other realms and their

tümer

are (cr)owned)

(Draesner 2014, p. 76)

In the near-homophonic interplay of 'bekränzt' (crowned) and 'begrenzt' (bordered), we see how this border between human and non-human is both celebrated and policed (captured in my translation by the play of 'crowned' and 'owned'). 'Tümer', which I leave untranslated, syntactically functions in combination with 'reiche' to suggest the word 'Reichtum', riches (as in 'other realms and their ( riches'), though the common suffix -tum, roughly equivalent to the English -dom, is not usually divided from the stem word in this fashion; elsewhere in the poem, Draesner uses 'tüm' as a standalone word or vocable. There are echoes here, too, of 'Ungetüm' (monster) and 'Ungestüm' (boisterousness, vehemence). Other poems are more ready to adopt the voices and perspectives of the birds themselves: in 'spätzchen, spatz' (little sparrow), for instance, the plural subjectivity of sparrows is set against the weakly singular perspective of human beings, again marked as other than birds by the fact we are 'über von haar bedeckt' (covered over in hair). Here, the overall sense is of how laughable and limited human beings are: unable to fly, violent, and locked into pathetic individuality.

For all that the collection is interested in how animals communicate, it would be wrong to locate Draesner's Subsong in the tradition of Romantic Natursprache. Rather than imagining that the non-human world contains the capacity to produce beautiful sound or even meaning for our human edification, Subsong draws complex parallels between how birds and humans communicate and create identity via sound. Draesner compares the formation of identity and subjectivity in birds and humans in numerous ways, but in the end emphasizes how, above all, we remain fundamentally other to each other or even antagonistic. As Evi Zemanek has argued in relation to Draesner's earlier writing, her work deconstructs the nature/culture dichotomy as a means of alerting us to man's destructive behavior (Zemanek 2017). The collection's overarching interest in the theme of voice-speaking 
through and with others, exploring the human and non-human worlds as imbricated and contingent on one another-locates Subsong firmly in the tradition of the new German nature lyric.

\section{The Lyric 'with Reference to a Vegetative Ensemble'}

The questions of form, voice, intermediality, and intertextuality which emerge in Draesner's Subsong are all aspects of an innovative approach to the genre of the lyric itself-since lyric poetry's defining feature is that it gives voice to subjective experience. The emergence of these new forms of lyric subjectivity is among the most important feature of the new German nature poetry. One can trace (as the introduction to this essay begins to) the history of German poetry in the twentieth century as a series of different approaches to the representation of the non-human world; representations of nature and environment are a key battleground for definitions of the German lyric.

Hans Magnus Enzensberger is among those who formulated this debate around the middle of the last century as the Brecht-Benn divide: the politically engaged poet with no time for beauty on the one hand, and the artisan with a firm belief in the autonomy of poetry on the other (Enzensberger 1963). Such crude distinctions have long since been debunked: Brecht wrote often, and vividly, about the beauty of nature, and Benn's poems are deeply rooted in forms of social intimacy and literary history which cannot but have socio-political implications. Yet the question of how, and whether, one can write poems about nature has consistently been a proxy for debates about the value and status of the lyric genre per se. Karl Krolow captured this in 1961, writing:

The (new nature) poems had a sort of numb quality: this numbness, from which they emerged, carried individuals along with it. Thus the individual human being became ever more part of 'nature', a being from whom any personality was removed, a creature amongst creatures, with the reactiveness and the dumb vegetable quality of all creatures. (... ) Such representations of humankind-with reference to a vegetative ensemble, always dependent upon it-signalled above all the 'dismantling' of the individual, he who perceives himself in all his individuality, who nourishes himself upon his individuality, who needs no 'connection' to depend on or to make his existence possible. (Krolow 1961)

For Krolow, this anti-anthropocentrism was misanthropic; removing mankind from the center of the cosmos left 'nature' in isolation, nothing more than a hollow concept, devoid of meaning, 'silent', vegetative. He saw this lack of specifically human subjectivity as incompatible with lyric poetry as a genre. The subject - the speaker - of lyric poetry, according to Krolow, had to be '(the individual) who perceives himself in all his individuality, who nourishes himself upon (it)'.

Poets working in German since 2010 have found new ways to restore lyric subjectivity to this material universe. They have done so by building on the approaches of the intervening generations, particularly earlier forms of Ökolyrik, and on approaches and theories from the Anglo-American context. Surveying the loose group of poets characterized here as representatives of a new German nature poetry, it is clear that their shared interest is in probing the boundaries of the human and non-human, of human and non-human representations of, and engagements with, environments and ecosystems. Instead of seeing human beings as distinct from the ecosystems they occupy, these poets position human subjectivity as part of the world in its totality, by exploring hybridized landscapes which show traces of human occupation, by using existing human representations of the non-human world to insert critical and aesthetic distance into their lyric subjectivity, and by blurring the boundaries of the human and non-human lyric subject altogether.

Hayer argues that the special power of the lyric is that it offers a particular space within which non-human subjectivity might be explored as a means of adopting an ecocritical stance. In Hayer's conception, the expression of non-human subjectivities in lyric poetry makes visible the possibilities that the lyric genre already offers for ecocriticism: poets 'use the resources of the lyric as a means of immediately accessing other perspectives' (Hayer 2018, p. 86). Yet the expressions of non-human, plural, and entangled subjectivity described in this article are a distinctive feature of recent German 
Naturlyrik —and there is more complexity and range in terms of the techniques adopted than Hayer's analysis proposes. Rather than simply exploiting existing possibilities for the purposes of expressing ecocritical ideas, contemporary German nature poets are actively creating new forms of hybridized, pluralized, and entangled lyric subjectivity. Thus, they reshape the lyric tradition per se, and the new German nature poetry expands the possibilities for poetry being written in German today.

Funding: This research received no external funding.

Conflicts of Interest: The author declares no conflicts of interest.

\section{References}

Arlaud, Sylvie. 2019. "Subsong" d'Ulrike Draesner. Sous-chants d'innocence et d'expériences. Germanica 64: 41-56. [CrossRef]

Bachmann, Ingeborg. 1998. Keine Delikatessen. In Sämtliche Gedichte. Munich: Piper, pp. 182-83.

Brecht, Bertolt. 1988. An die Nachgeborenen. In Werke. Frankfurt a. M.: Suhrkamp, vol. 12, pp. 85-87.

Diez, Georg. 2015. S.P.O.N.-Der Kritiker: Weg mit all den Weidenkätzchen! Spiegel Online. March 13. Available online: https://www.spiegel.de/kultur/gesellschaft/jan-wagner-regentonnenvariationen-undleipziger-buchmesse-a-1023422.html (accessed on 21 May 2020).

Draesner, Ulrike. 2014. Subsong. Munich: Luchterhand.

Ebel, Martin. 2014. Was der Löwenzahn über den Menschen spricht. Basler Zeitung. November 23. Available online: https://www.bazonline.ch/kultur/buecher/was-der-loewenzahn-ueber-den-menschen-spricht/story/ 17531920 (accessed on 7 May 2020).

Enzensberger, Hans Magnus. 1963. In Search of the Lost Language. Encounter 21: 44-51.

Geist, Peter. 2009. Mit Dolly im "Second life". Junge deutschsprachige Lyrik nach der Natur. In Das Angesicht der Erde. Brechts Ästhetik der Natur. Recherchen 66. Edited by Sebastian Kleinschmidt. Berlin: Theater der Zeit.

Goodbody, Axel. 1984. Natursprache: Ein Dichtungstheoretisches Konzept der Romantik und seine Wideraufnahme in der Modernen Naturlyrik. Neumünster: Wachholtz.

Goodbody, Axel. 2016. Naturlyik-Umweltlyrik-Lyrik im Anthropozän. In all dies hier, Majestät, ist deins: Lyrik im Anthropozän. Edited by Anja Bayer and Daniela Seel. Berlin: kookbooks, pp. 287-305.

Goodbody, Axel. 2017. German Ecopoetry: From "Naturlyrik" (Nature Poetry) and "Ökolyrik" (Environmental Poetry) to Poetry in the Anthropocene. In Ecological Thought in German Literature and Culture. Edited by Gabriele Duerbeck, Urte Stobbe, Hubert Zapf and Evi Zemanek. Lanham: Lexington Books, pp. 263-80.

Haraway, Donna. 1988. Situated Knowledges: The Science Question in Feminism and the Privilege of Partial Perspective. Feminist Studies 14: 575-99. [CrossRef]

Haraway, Donna. 2015. Anthropocene, Capitalocene, Plantationocene, Chthulucene: Making Kin. Environmental Humanities 6: 159-65. [CrossRef]

Hayer, Björn. 2018. Flora im Widerstand: Subjektivität als ökokritische Haltung in der zeitgenössischen Lyrik: Marion Poschmann, Silke Scheuermann und Jan Wagner. In Ökologischer Wandel in der deutschsprachigen Literatur des 20. und 21. Jahrhunderts. Edited by Gabriele Dürbeck, Christine Kanz and Ralf Zschachlitz. Berlin: Peter Lang, pp. 71-90.

Kohlross, Christian. 2000. Theorie des modernen Naturgedichts: Oskar Loerke -Günter Eich-Rolf Dieter Brinkmann. Würzburg: Königshausen \& Neumann.

Kopisch, Wendy Anne. 2012. Naturlyrik im Zeichen der ökologischen Krise: Begrifflichkeiten-Rezeption-Kontexte. Kassel: Kassel University Press.

Krolow, Karl. 1961. Aspekte Zeitgenössischer Deutscher Lyrik, 2nd ed. Gütersloh: Mohn.

Leeder, Karen. 2018. "I Am a Double-Voiced ( ... ) Bird": Identity and Voice in Ulrike Almut Sandig's Poetry. Oxford German Studies 47: 329-50. [CrossRef]

Rigby, Kate. 2016. Earth's Poesy: Romantic Poetics, Natural Philosophy, and Biosemiotics. In Handbook of Ecocriticism and Cultural Ecology. Edited by Hubert Zapf. Berlin: De Gruyter, pp. 45-64. [CrossRef]

Sandig, Ulrike Almut. 2011. Dickicht. Frankfurt a. M.: Schöffling.

Sandig, Ulrike Almut. 2016. ich bin ein Feld Voller Raps Verstecke die Rehe und Leuchte wie Dreizehn Ölgemälde übereinandergelegt. Frankfurt am Main: Schöffling.

Scheuermann, Silke. 2014. Skizze vom Gras. Frankfurt a. M.: Schöffling. 
Studio Olafur Eliasson. n.d. Spiral Pavilion. Available online: https://olafureliasson.net/archive/artwork/ WEK101392/spiral-pavilion (accessed on 7 May 2020).

Tarlo, Harriet. 2009. Recycles: The Eco-Ethical Poetics of Found Text in Contemporary Poetry. Journal of Ecocriticism 1: 114-30.

Tawada, Yoko. 2012. Fremde Wasser. Edited by Ortrud Gutjahr. Tübingen: Konkursbuch.

Tawada, Yoko. 2016. Ein Balkonplatz für flüchtige Abende. Tübingen: Konkursbuch.

von Eichendorff, Joseph. 1981. Wünschelrute. In Werke. Munich: Hanser, vol. 1, p. 103.

Wagner, Jan. 2016. Regentonnenvariationen. Frankfurt a. M.: Fischer.

Wagner, Jan. 2017. The Poetry Society Annual Lecture. Poetry Review 107. Available online: http://poetrysociety. org.uk/publications/volume-107-no-1-spring-2017/ (accessed on 7 May 2020).

Wagner, Jan. 2018. Die Live Butterfly Show. Munich: Hanser.

Welch, Tana Jean. 2014. Entangled Species: The Inclusive Posthumanist Ecopoetics of Juliana Spahr. Journal of Ecocriticism 6: 1-25.

Zemanek, Evi. 2017. Elemental Poetics. In Ecological Thought in German Literature and Culture. Edited by Gabriele Duerbeck, Urte Stobbe, Hubert Zapf and Evi Zemanek. Lanham: Lexington Books, pp. 281-96.

(C) 2020 by the author. Licensee MDPI, Basel, Switzerland. This article is an open access article distributed under the terms and conditions of the Creative Commons Attribution (CC BY) license (http://creativecommons.org/licenses/by/4.0/). 